\title{
Inferring snowpack ripening and melt-out from distributed measurements of near-surface ground temperatures
}

\author{
M.-O. Schmid, S. Gubler, J. Fiddes, and S. Gruber \\ Department of Geography, University of Zürich, Switzerland \\ Correspondence to: M.-O. Schmid (marc-olivier.schmid@geo.uzh.ch) \\ Received: 13 January 2012 - Published in The Cryosphere Discuss.: 10 February 2012 \\ Revised: 25 August 2012 - Accepted: 10 September 2012 - Published: 15 October 2012
}

\begin{abstract}
Seasonal snow cover and its melt regime are heterogeneous both in time and space. Describing and modelling this variability is important because it affects diverse phenomena such as runoff, ground temperatures or slope movements. This study presents the derivation of melting characteristics based on spatial clusters of ground surface temperature (GST) measurements. Results are based on data from Switzerland where ground surface temperatures were measured with miniature loggers (iButtons) at 40 locations referred to as footprints. At each footprint, up to ten iButtons have been distributed randomly over an area of $10 \mathrm{~m} \times 10 \mathrm{~m}$, placed a few $\mathrm{cm}$ below the ground surface. Footprints span elevations of $2100-3300 \mathrm{~m}$ a.s.l. and slope angles of $0-55^{\circ}$, as well as diverse slope expositions and types of surface cover and ground material. Based on two years of temperature data, the basal ripening date and the melt-out date are determined for each iButton, aggregated to the footprint level and further analysed. The melt-out date could be derived for nearly all iButtons; the ripening date could be extracted for only approximately half of them because its detection based on GST requires ground freezing below the snowpack. The variability within a footprint is often considerable and one to three weeks difference between melting or ripening of the points in one footprint is not uncommon. The correlation of mean annual ground surface temperatures, ripening date and melt-out date is moderate, suggesting that these metrics are useful for model evaluation.
\end{abstract}

\section{Introduction}

Seasonal snowmelt is important for mountain hydrology and water supply to lowlands (Viviroli and Weingartner, 2004); it can contribute to the triggering of landslides and debris flows (Iverson et al., 1997; Wirz et al., 2011) and it is linked to many other physical and ecological processes and phenomena. Depending on environmental conditions, two distinct points in time can be recognized that help to quantify the temporal patterns of snowmelt. The melt-out date (MD) describes the time when the snow cover is depleted and no further release of meltwater occurs, allowing the ground surface to warm above $0{ }^{\circ} \mathrm{C}$. The basal-ripening date (RD) describes the time when a frozen ground surface is warmed to $0^{\circ} \mathrm{C}$ by melt-water percolation or by strong rain-on-snow events (cf. Westermann et al., 2011). RD can only be detected in situations having negative temperatures at the snow-ground interface. In this paper, we use near-surface ground temperature, measured at depths of a few centimetres, as a proxy of ground surface temperature (GST).

MD can be investigated using optical space-borne (Bitner et al., 2002; Li and Wang, 2011; Parajka and Blöschl, 2008) or ground-based (Schmidt et al., 2009) remote sensing. Furthermore, attempts have been made to detect RD with optical space-borne remote sensing (Foster et al., 2011; Lampkin and Yool, 2004). On the ground, measurements are feasible by means of miniature temperature loggers (Etzelmüller et al., 2007; Gadek and Leszkiewicz, 2010; Hoelzle et al., 1999, 2003), hand tests (Techel and Pielmeier, 2011) or as part of more comprehensive measurement stations (Lehning et al., 1999). First studies using GST to monitor snow cover evolution were carried out in North America (Lundquist and Lott, 2008; Tyler et al., 2008). Patterns of snowpack evolution and melting are usually heterogeneous both in time and space, especially in mountain regions. This is because topography influences snow redistribution by wind and avalanches, surface micrometeorology and also the 
distribution of ground material. Grid-based snow cover distribution models are often used to estimate snow cover evolution (e.g. Bartelt and Lehning, 2002; Blöschl et al., 1991a, b; Lehning et al., 2002a, b; Luce et al., 1998) or ground temperatures (Dall'Amico et al., 2011; Luetschg and Haeberli, 2005). Scales of gridded applications range from grid sizes of few meters (e.g. Groot Zwaaftink et al., 2011; Marsh et al., 2012) to tens or hundreds of kilometers in climate models (e.g. Best et al., 2011; Essery and Clark, 2003; Tribbeck et al., 2004). Often, the interaction with vegetation (e.g. Endrizzi and Marsh, 2010; Rutter et al., 2009) and processes of snow redistribution (e.g. Groot Zwaaftink et al., 2011; Pomeroy et al., 1997) are simulated as well. While Anderton et al. (2002) show that the micro-scale spatial variability of the snow cover needs to be taken into account to model snowmelt at larger scales, most data products for the evaluation of models are based on satellite data with rather coarse resolution (Brown, 2000; Dyer and Mote, 2006; Gutzler and Rosen, 1992; Scherrer, 2006). In contrast to this, the role of topography and fine-scale variability of snow cover evolution is investigated in a number of local studies by, e.g. Jost et al. (2007), López-Moreno et al. (2011), Grünewald et al. (2010), and Schmidt et al. (2009).

In the validation of grid-based models, point measurements are often implicitly assumed to adequately represent the area around them that constitutes a model cell. Variation at distances smaller than the grid used, however, can confound such studies by hiding the larger-scale landscape signal under investigation. This is especially true when small numbers of single-point measurements distributed over a landscape are used, which is a typical situation due to the high cost of site access in many cases. Gubler et al. (2011) showed that even within a distance of less than $15 \mathrm{~m}$, mean annual ground surface temperatures (MAGST) can exhibit a range of more than $2{ }^{\circ} \mathrm{C}$. Based on the same measurements but with a duration of two years, we investigate the potential of GST to provide reliable, inexpensive and distributed information about MD and RD. Specifically, we investigate (a) how to derive MD and RD in diverse topographic situations, and (b) how fine-scale variability affects the relationship between point measurements and grid-based representations with the aim to inform studies that validate grid-based models based on few point measurements.

\section{Data}

\subsection{Research area and meteorological conditions during the measurement period}

This study is based on the dataset described by Gubler et al. (2011) for which two measurement years are now available. The study area is situated around Piz Corvatsch, a mountain in the Eastern Swiss Alps, close to St. Moritz. The $0{ }^{\circ} \mathrm{C}$ isotherm of the mean annual air temperature (MAAT) is situated at an altitude of about $2200 \mathrm{~m}$ a.s.l. The investigation area extends above $3000 \mathrm{~m}$ a.s.l. and is partially subject to permafrost conditions. The western and northern flanks of Piz Corvatsch feature large debris slopes and several rock glaciers, whereas further south in the Furtschellas area, inactive and relict rock glaciers are present. Figure 1 shows a map of the measuring locations.

Air temperature from which the MAAT is derived is measured by MeteoSwiss at Piz Corvatsch in the research area and at the nearby weather stations Passo del Bernina and Samedan. The 2011 period (20 August 2010 to 19 August 2011) was between $0.2{ }^{\circ} \mathrm{C}$ and $0.47^{\circ} \mathrm{C}$ warmer than the 2010 period (20 August 2009 to 19 August 2010). Both were warmer than the normal period 1961-1990. The snow cover development at nearby stations during both winters was relatively similar to the long-term average. Snow heights in winter 2009/2010 were slightly above average and in 2010/2011 slightly below average. MD at Passo del Bernina and Samedan was earlier in 2011 than in 2010 (Fig. 3). Both periods had strong snowfall outside the winter season: significant events occurred in mid June and early October 2010 (Pielmeier, 2011; Stucki, 2010).

\subsection{Measurement design}

Miniature temperature loggers iButton ${ }^{\circledR}$ DS1922L with a resolution of $0.0625^{\circ} \mathrm{C}$ were programmed to record GST every three hours, allowing for more than one year of autonomous operation with the memory available. The accuracy is stated to be $\pm 0.5^{\circ} \mathrm{C}$ by the manufacturer and has been determined to be $\pm 0.125^{\circ} \mathrm{C}$ near $0{ }^{\circ} \mathrm{C}$ by Gubler et al. (2011). In July and August 2009, 390 iButtons were distributed within 40 so-called footprints. These span diverse topographic situations with elevations of 2100-3300 m a.s.l., slope aspects north, south, east, and west, slope angles of $0-55^{\circ}$ and various ground cover types (GCT). Each footprint consists of up to ten iButtons randomly placed within $10 \mathrm{~m} \times 10 \mathrm{~m}$ in order to capture small-scale variability. The devices were generally buried a few $\mathrm{cm}$ below the ground surface at locations with no fine-grained material (i.e. exposed bedrock), placed in voids in the ground. Programming and read-out were facilitated by the software iAssist (Keller et al., 2010). A digital elevation model with a resolution of $10 \mathrm{~m}$ (SwissPhoto) was used to derive elevation, slope angle and slope exposition of all footprints. The GCT classification defined by Schmid (2011) and Gubler et al. (2011) was used: GCT1 is fine-grained, sometimes partly organic material; GCT3 consists of large boulders (e.g. on rock glaciers); and GCT2 is an intermediate type between the two. GCT4 is characterized by strongly heterogeneous and steep footprints partially composed of bedrock.

In July and August 2010, 368 of 390 iButtons were retrieved and contained GST measurements for one year. In August 2011, 357 iButtons were recovered and 355 contained complete GST time-series. The one-year periods used 


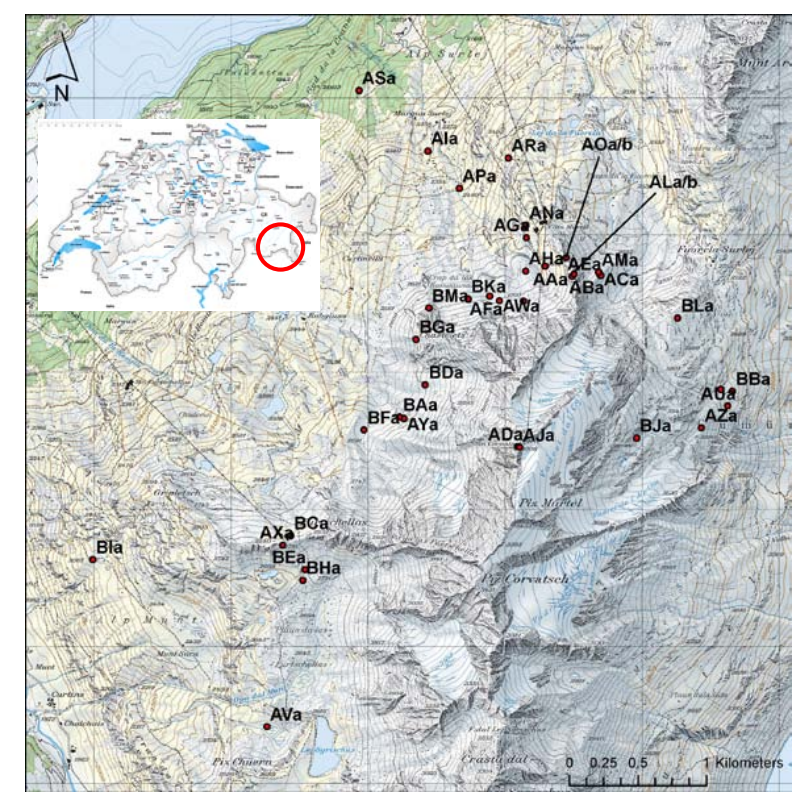

Fig. 1. Research area around Piz Corvatsch (south-eastern Switzerland) with locations of all footprints.

for analysis range from 20 August to 19 August and are here referred to as 2010 and 2011, indicating the year of data readout. iButtons found on the surface during read-out were excluded from subsequent analysis because exposure to solar radiation may have affected their temperature. This resulted in $92 \%$ (first year) and $89 \%$ (second year) of valid time series. Data gaps during read-out have a maximum length of one day and are filled by linear interpolation between adjacent measurements. The analyses shown here are based on 343 iButtons from the 2010 period, 348 iButtons from 2011 and 338 iButtons with valid data spanning both years. The snow cover was measured at most sites during three campaigns in January, March and April in 2010 (Gubler et al., 2011; Schmid, 2011). At each measured footprint, ten snowheight measurements and one SWE measurement were made (Table 1). At all sites, a snow-free period occurs in late summer and autumn.

\section{Methods}

\subsection{Melt-out date}

Due to its low thermal conductivity, snow insulates the ground from the cold atmosphere during winter (Goodrich, 1982) and in several studies this effect is used to detect a snow cover based on GST time series. Based on the daily variance of GST, Danby and Hik (2007) considered a threshold of $1{ }^{\circ} \mathrm{C}$ (4 h sampling rate), and Schmidt et al. (2009) one of $0.09{ }^{\circ} \mathrm{C}(1 \mathrm{~h}$ sampling rate) to indicate snow-covered ground. Gadek and Leszkiewicz (2010) estimated the pres-
Table 1. Snow measurements from winter 2009/10, all values are in $\mathrm{mm}$. Snow heights are based on 10 randomly chosen measurement points. SWE was measured in the centre of each footprint and adapted accordingly to the mean height.

\begin{tabular}{|c|c|c|c|c|c|c|}
\hline \multirow{2}{*}{$\begin{array}{l}\text { Foot- } \\
\text { print }\end{array}$} & \multicolumn{2}{|c|}{ 30.01.-02.02.2010 } & \multicolumn{2}{|c|}{ 12. $-14.03 .2010$} & \multicolumn{2}{|c|}{ 23. $-25.4 .2010$} \\
\hline & height & SWE & height & SWE & height & SWE \\
\hline AA & 600 & 160 & 620 & 214 & NA & NA \\
\hline $\mathrm{AD}$ & 135 & 50 & 225 & 60 & 142 & 45 \\
\hline $\mathrm{AE}$ & 1210 & 508 & NA & NA & NA & NA \\
\hline $\mathrm{AF}$ & 1406 & NA & NA & NA & NA & NA \\
\hline $\mathrm{AH}$ & 1350 & 466 & 1560 & 531 & NA & NA \\
\hline $\mathrm{AI}$ & NA & NA & 1490 & NA & 1160 & 431 \\
\hline AJ & 790 & NA & 460 & 172 & NA & NA \\
\hline $\mathrm{AK}$ & 1460 & 435 & NA & NA & NA & NA \\
\hline $\mathrm{AL}$ & 1833 & 627 & NA & NA & NA & NA \\
\hline AN & 1395 & 457 & 1660 & 564 & 2050 & 741 \\
\hline $\mathrm{AP}$ & 1320 & 453 & 1590 & 607 & 1685 & 528 \\
\hline $\mathrm{AQ}$ & 1067 & 276 & 2080 & 592 & NA & NA \\
\hline $\mathrm{AR}$ & 1450 & 549 & 1240 & 488 & 1810 & 711 \\
\hline AS & 1460 & 373 & 1560 & 535 & 1190 & 394 \\
\hline AT & 1580 & 463 & 520 & 182 & NA & NA \\
\hline $\mathrm{AU}$ & 1005 & 283 & NA & NA & NA & NA \\
\hline AW & 1600 & 500 & 1580 & 564 & NA & NA \\
\hline AY & 1610 & 541 & 1830 & 614 & NA & NA \\
\hline $\mathrm{AZ}$ & 1705 & 537 & 1920 & 714 & 1915 & 720 \\
\hline BA & 1210 & 332 & 870 & 249 & NA & NA \\
\hline $\mathrm{BC}$ & 1855 & 594 & 1800 & 617 & 2500 & 1210 \\
\hline BD & 1200 & 315 & 1540 & 607 & NA & NA \\
\hline $\mathrm{BE}$ & 905 & 266 & 1240 & 448 & 718 & 335 \\
\hline $\mathrm{BH}$ & 1145 & 415 & 1870 & 788 & 2009 & 798 \\
\hline BJ & 1320 & 386 & 1943 & 695 & 1820 & 663 \\
\hline
\end{tabular}

ence of a snow cover simply based on days with GST $\leq 0{ }^{\circ} \mathrm{C}$. All three approaches are based on rather small range of environmental conditions and, when applied to the large dataset of this study yield only partially satisfying results. The following observations are made based on visually inspecting time series of GST and their daily variance: (a) most locations clearly show the presence of an insulating snow cover during winter, few locations clearly show the absence of it, and some appear to lie in between. (b) The beginning of a snow cover, which at the time may be thin and provide little insulation, is more difficult to detect than the date of its melt-out (MD). (c) Detection of MD based on daily variance alone is unreliable and leads to spurious snow-free periods during winter. Furthermore, snow-cover days are overestimated at locations with a generally low daily GST variance when using fixed thresholds. (d) Detection of MD based on temperature alone is unreliable because low-elevation sites can maintain positive temperatures a few centimeters below the ground surface for prolonged periods when a thick snow cover is present.

As the detection of MD requires an insulating snow cover, we define a snow-cover reliability index (MDr) based on the mean daily standard deviation of GST during January, February and March: 
$\mathrm{MDr}=0.2-\sigma\left(\mathrm{GST}_{\mathrm{Jan}-\mathrm{Mar}}\right)$.

This threshold of 0.2 has been determined subjectively, based on visual interpretation of GST and its daily variance during winter. The sensitivity to the chosen threshold is relatively low, with a change of the sample size selected being smaller than $10 \%$ when changing the threshold by $50 \%$ (Fig. 2). If $\mathrm{MDr}$ is greater than zero, we assume that the insulation effect of the snow cover is sufficient to allow the reliable derivation of MD. For iButtons with $\mathrm{MDr}>0$, days with a snow cover were detected based on the daily standard deviation. If the daily mean GST is positive, we chose a threshold of $0.1^{\circ} \mathrm{C}$, and if the daily mean GST is negative, we chose a threshold of $0.3^{\circ} \mathrm{C}$. Two different thresholds are necessary because, for days with negative GST, mostly the thermal insulation of the snow cover affects the standard deviation. Positive GST, however, can only occur under a partly wet snow cover where temperature fluctuations are additionally damped by phase change. Spurious gaps were closed for days with GST $\leq 0.5^{\circ} \mathrm{C}$. Days with a maximum GST $>3{ }^{\circ} \mathrm{C}$ are considered snow-free based on observations at the lowest site (2100 $\mathrm{m}$ a.s.l.). MD is defined as the end date of the snow cover period with the longest duration. It is aggregated to the footprint level as a mean value. Where MD could not be detected for all iButtons in a footprint, it was calculated if at least five values were available.

\subsection{Basal ripening date}

In many places, temperatures below $0{ }^{\circ} \mathrm{C}$ seasonally prevail in the snowpack and the ground below (Gubler et al., 2011). Liquid water originating from surface melting or rain infiltrates and warms deeper layers through the release of latent heat during freezing (Westermann et al., 2011). Once the meltwater reaches the ground surface and warms it to $0^{\circ} \mathrm{C}$, the snowpack above is mostly isothermal at a temperature of $0^{\circ} \mathrm{C}$, with the exception of refreezing near the surface during clear nights or cold periods. This point in time, the ripening date $(\mathrm{RD})$, is detected as the beginning of the zero curtain period (defined here as the duration of the zero curtain effect, which is the effect of latent heat in maintaining temperatures near $0{ }^{\circ} \mathrm{C}$ over extended periods in freezing or thawing soils, e.g. Outcalt et al., 1990) in spring and marks the beginning of meltwater runoff or percolation into the ground (Taras et al., 2002; Tyler et al., 2008). The development of preferential flow paths in snow (Williams et al., 2010) increases the lateral variability between cold and isothermal portions of the snowpack and ground below and, as a consequence, also the lateral variability of RD. Commonly, no cooling below $0^{\circ} \mathrm{C}$ takes place at the ground surface after the RD; sometimes however, cold conditions can cause a complete refreezing of the melting snowpack and interrupt the zero curtain period in shallow ground levels below.

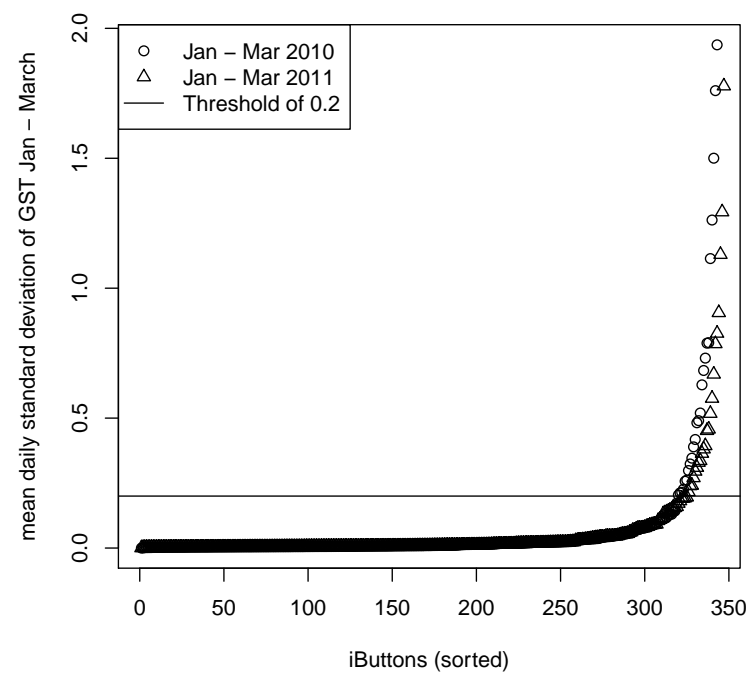

Fig. 2. Mean daily standard deviation of GST from January to March. The horizontal line indicates the threshold of 0.2 . The obvious knee in the curve represents the separation between an insulating- and a non-insulating snow cover with one threshold. The sensitivity to the chosen threshold is relatively low, as shown by a change in the applied threshold of $50 \%$ causes a change in the selected sample size of less than $10 \%$.

$\mathrm{RD}$ can only be determined together with MD for locations where the ground surface is frozen underneath the snowpack. This is expressed in the RD reliability index:

$\mathrm{RDr}=\left\{\begin{array}{l}-50-\mathrm{FDD} \text { if } \mathrm{MDr}>0 \\ 0 \text { if } \mathrm{MDr} \leq 0\end{array}\right.$,

where FDD is the sum of negative daily mean GST during the snow-cover period with the longest duration. Only for $\mathrm{RDr}>0$ is RD derived. This is because zero curtain periods during freezing can only be distinguished from those during thawing if the ground can clearly be detected as frozen in between. At many low-elevation footprints, iButtons did not record negative temperatures, making it impossible to detect the start of an isothermal snowpack.

Based on the calibration reported by Gubler et al. (2011), days with GST between $-0.25{ }^{\circ} \mathrm{C}$ and $0.25^{\circ} \mathrm{C}$ were defined as a zero curtain period. RD was then detected as the beginning of zero-curtain days after the longest period having a daily mean GST smaller than $-0.25^{\circ} \mathrm{C}$. RD is aggregated to the footprint level as a mean value. Where RD could not be detected for all iButtons in a footprint, it was calculated if at least five values were available.

\subsection{Mean annual ground surface temperature}

Mean annual ground surface temperature (MAGST) is a useful measure characterising the ground thermal regime of a location. It was calculated as the mean of all measurements per iButton. Due to the fact that at all footprints at least five 


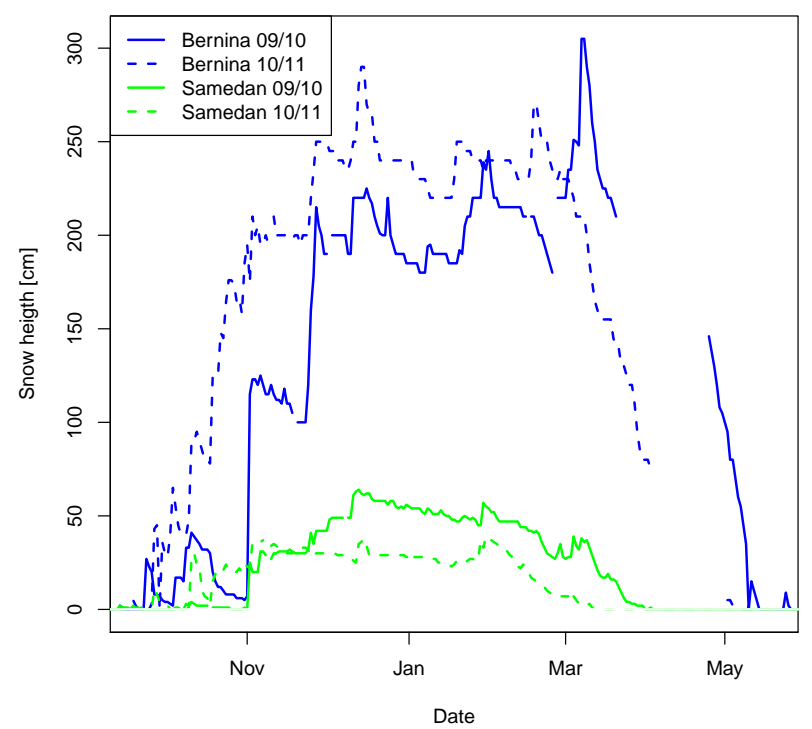

Fig. 3. Snow height at Passo del Bernina and Samedan during the winters 2009/10 and 2010/11 (source: MeteoSwiss).

measurement series were recorded, the MAGST could be aggregated to the footprint level at all locations.

\subsection{Algorithm testing with modelled data}

We tested our algorithm based on simulations for which MD can be determined independently of GST. We performed numerical experiments with the open-source and physicallybased numerical model GEOtop that accounts for heat and water transfer in soil, including effects of phase change and partial saturation (Dall'Amico et al., 2011). GEOtop contains a multi-layer snowpack that accommodates compaction as well as water percolation and refreezing. The influence of topography on micro-climatology is parameterized, allowing for the solution of the surface energy balance for differing topographic situations, based on one driving climate time series (Endrizzi and Marsh, 2010). A distributed version of GEOtop exists but in this study, a one-dimensional mode was employed. In these experiments, the lower boundary condition was given by a zero heat and mass flux. Lateral drainage was parameterized by a free surface that can be placed at arbitrary distance below the surface. Snow was discretized into ten layers, which are finer near the interfaces with the atmosphere and the soil than in the middle of the snowpack. The thickness of the 14 soil layers was parameterized by where $\mathrm{n}$ is the layer number from the surface downwards, $a=1.5$ governs the thickening of layers with depth and $z_{\min }=20 \mathrm{~mm}$ is the thickness of the top layer. The depth of the deepest node is $8.8 \mathrm{~m}$. The system was initialized with a starting temperature of $-1{ }^{\circ} \mathrm{C}$ and spun up from August 1986 to April 2005. Output was then generated for the period May 2005 to October 2011 with an interval of $3 \mathrm{~h}$, corresponding to the iButton measurements. Model out- put consisted of mean ground temperatures at depths of 10 , 50 and $100 \mathrm{~mm}$ as well as snow water equivalent (SWE). A large number of hypothetical points were simulated to test the robustness of the method. These were defined by elevation $(2000 \mathrm{~m}, 2500 \mathrm{~m}, 3000 \mathrm{~m}, 3500 \mathrm{~m})$, slope aspect (north, east, south, west), slope angle $\left(0^{\circ}, 20^{\circ}, 40^{\circ}\right)$, lateral drainage (free surface at 10 and $2000 \mathrm{~mm}$ depth), soil type (silt, sand, gravel, rock) and precipitation altered by a factor $(0.5,1,2)$ to approximate high accumulation and low accumulation terrain facets.

The algorithm developed for the iButton dataset to detect MD was then driven with modelled ground temperatures and the results were compared to the MD based on the modelled SWE. Simulated points for which the minimum SWE during a year was larger than 0 were excluded.

This simulation-based approach is preferred over validation with field data because the scale difference between a ground temperature measurement and conventional snow height sensors is likely to challenge the interpretation of results. Usually installed at 4-7 m height, their opening angle of around $20^{\circ}$ (e.g. SR50, Campbell Scientific) caused them to integrate over an area with an approximate diameter of $1.5-4 \mathrm{~m}$, much larger than that measured by an iButton. A future option for validation is a high-resolution automatic camera pointed at one footprint containing several iButtons, but this has not been pursued in the current study.

\section{Results}

\subsection{Algorithm testing}

In Fig. 4, the difference between the MD based on GST and the MD based on the SWE is shown with simulated data from five years. The different boxes represent the modelled GST depths. The number of detected MD increases as the depth shifts from $10 \mathrm{~mm}$ to $50 \mathrm{~mm}$ to $100 \mathrm{~m}$. The detected MD shifts slightly towards a later date with increasing depth. In general, detected MD from all depths fit very well with MD based on SWE with maximum differences of one day for $99 \%$ of the simulated points at $10 \mathrm{~mm} ; 97 \%$ at $50 \mathrm{~mm}$ and $85 \%$ at $100 \mathrm{~mm}$ depth.

\subsection{General description}

In Fig. 5, typical characteristics of the measured locations are exemplified: iButton ALa04 is located on a ridge composed of gravel. After the freezing of the ground in autumn, the GST is strongly damped with respect to the atmosphere during winter, indicating the presence of an insulating snow cover. In spring, a zero curtain period occurs. For this device it is possible to detect both the RD and the MD. iButton ASa10 is located in a forest glade at $2100 \mathrm{~m}$ a.s.l. The insulating snow cover prevents the ground from freezing, and therefore MD but not RD was detected. iButton $\mathrm{AOa} 03$ classified as GCT4 has a standard deviation of 0.19 , which is the 
Table 2. Standard deviations of the intra-footprint and interfootprint scale.

\begin{tabular}{|c|c|c|c|c|c|c|}
\hline \multirow{2}{*}{$\begin{array}{l}\text { Mean } \\
\text { standard } \\
\text { deviation }\end{array}$} & \multicolumn{2}{|c|}{ RD [days] } & \multicolumn{2}{|c|}{ MD [days] } & \multicolumn{2}{|c|}{ MAGST $[\mathrm{C}]$} \\
\hline & 2010 & 2011 & 2010 & 2011 & 2010 & 2011 \\
\hline Intra-footprint & 6 & 5 & 8 & 8 & 0.33 & 0.33 \\
\hline Inter-footprint & 26 & 21 & 22 & 29 & 2.19 & 2.08 \\
\hline
\end{tabular}

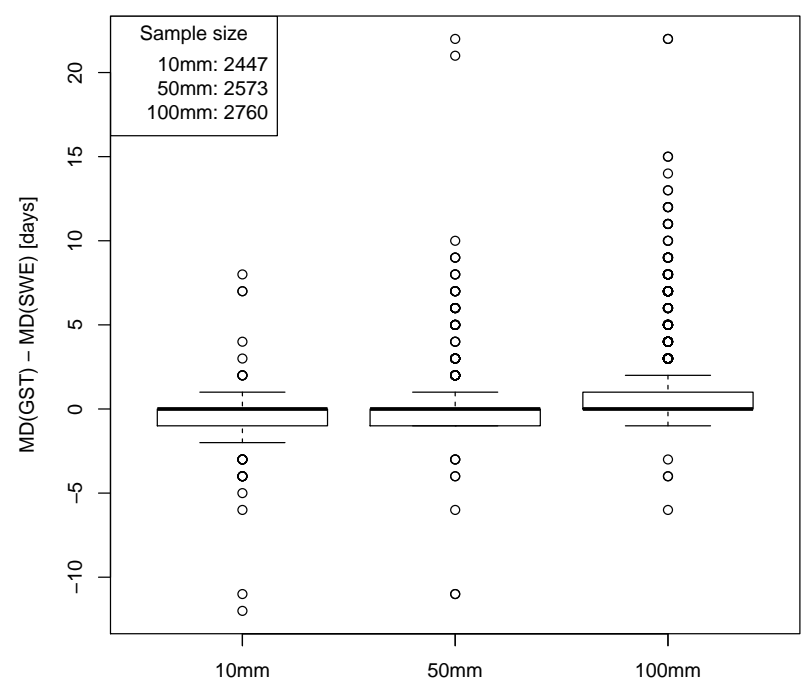

Depth of ground temperature used to approximate GST

Fig. 4. MD based on SWE compared to MD based on GST from three different depths. Both SWE and GST were modelled with GEOtop. The length of the whiskers is 1.5 times the interquartile range.

highest value where we still predict an insulating snow cover. An overview with the number of valid iButtons per footprint and the number of detected MD and RD is in Table 3.

\subsection{Intra-footprint variability}

MD was detected in 2010 for 319 iButtons and in 2011 for 325. In both years, average values for footprint $\mathrm{AGa}$ and $\mathrm{AOa}$ were not calculated and in 2011 also AJa and AOb had to be excluded due to the absence of an insulating snow cover. The mean standard deviation of MD per footprint in both years is 8 days (Table 2). RD could be calculated only for approximately half the iButtons due to a lack of snow or ground freezing. Lack of snow was frequent on footprints of GCT 4 and lack of ground freezing mostly occurred at low-elevation sites. In 2010, RD could be calculated for 178 iButtons and aggregated for 20 footprints, and in 2011 for 167 iButtons or 16 footprints. A mean value per footprint over both years is calculated for 14 locations. The mean standard deviation of RD per footprint is 5 and 6 days. Table 2 shows the standard deviation to be expected within a radius of several meters, based on all footprints with at least
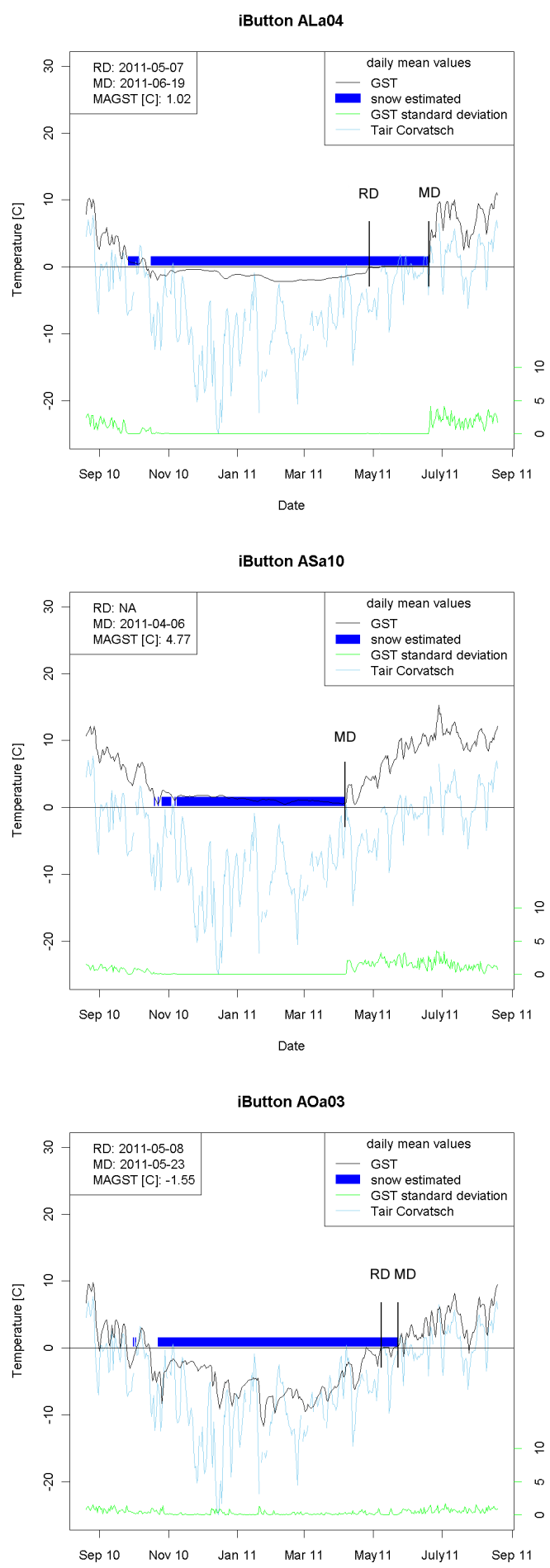

Date

Fig. 5. Typical examples of temperature evolution. For all three iButtons an insulating snow cover is present. For ALa10, RD and MD are detected, whereas for ASa10, only MD can be detected. At $\mathrm{AOa} 03, \mathrm{MD}$ and RD were detected as well, but with a mean standard deviation of the GST (Jan-Mar) of 0.19, it is the location with the highest value where we still predict an insulation snow cover. 
Table 3. List of footprints and the amount of GST, MD and RD values derived. The lack of an insulating snow cover resulted in iButtons where MD was not detected. The lack of a clearly frozen ground resulted in snow covered iButtons where RD was not detected, except for some locations with GCT4 where no zero curtain phase occurred (marked with ${ }^{*}$ ). Elevation, slope angle and slope exposition are based on a $10 \mathrm{~m}$ digital elevation model.

\begin{tabular}{|c|c|c|c|c|c|c|c|c|c|c|}
\hline \multirow[b]{2}{*}{ Footprint } & \multirow[b]{2}{*}{ Elevation } & \multirow[b]{2}{*}{ Slope } & \multirow[b]{2}{*}{ Aspect } & \multirow[b]{2}{*}{ GCT } & \multicolumn{3}{|c|}{2010} & \multicolumn{3}{|c|}{2011} \\
\hline & & & & & GST & MD & $\mathrm{RD}$ & GST & $\mathrm{MD}$ & $\mathrm{RD}$ \\
\hline AAa & 2694 & 38 & 251 & 1 & 10 & 10 & 8 & 10 & 10 & 0 \\
\hline $\mathrm{ABa}$ & 2745 & 16 & 96 & 2 & 10 & 10 & 3 & 10 & 10 & 5 \\
\hline $\mathrm{ACa}$ & 2743 & 31 & 112 & 2 & 10 & 10 & 7 & 10 & 10 & 8 \\
\hline $\mathrm{ADa}$ & 3303 & 29 & 263 & 4 & 10 & 5 & 5 & 10 & 8 & $7^{*}$ \\
\hline $\mathrm{AEa}$ & 2826 & 29 & 290 & 1 & 10 & 9 & 9 & 10 & 10 & 10 \\
\hline $\mathrm{AFa}$ & 2689 & 23 & 9 & 4 & 10 & 10 & 10 & 10 & 9 & 9 \\
\hline $\mathrm{AGa}$ & 2664 & 48 & 243 & 4 & 10 & 2 & 2 & 10 & 3 & 3 \\
\hline $\mathrm{AHa}$ & 2663 & 9 & 318 & 3 & 10 & 10 & 10 & 10 & 10 & 10 \\
\hline AIa & 2307 & 18 & 330 & 1 & 4 & 4 & 0 & 6 & 6 & 2 \\
\hline $\mathrm{AJa}$ & 3302 & 27 & 113 & 4 & 10 & 5 & $4^{*}$ & 10 & 4 & $2^{*}$ \\
\hline ALa & 2824 & 14 & 347 & 1 & 4 & 4 & 4 & 4 & 4 & 4 \\
\hline $\mathrm{ALb}$ & 2824 & 25 & 60 & 1 & 5 & 5 & 5 & 5 & 5 & 3 \\
\hline AMa & 2738 & 30 & 333 & 2 & 10 & 10 & 10 & 10 & 10 & 10 \\
\hline $\mathrm{ANa}$ & 2673 & 25 & 252 & 1 & 9 & 9 & 0 & 9 & 9 & 0 \\
\hline $\mathrm{AOa}$ & 2811 & 36 & 64 & 4 & 5 & 2 & 2 & 5 & 1 & 1 \\
\hline $\mathrm{AOb}$ & 2811 & 18 & 238 & 4 & 5 & 5 & 5 & 5 & 4 & 4 \\
\hline $\mathrm{APa}$ & 2405 & 15 & 335 & 1 & 1 & 1 & 0 & 1 & 1 & 0 \\
\hline AQa & 2729 & 29 & 12 & 3 & 10 & 10 & 10 & 10 & 10 & 10 \\
\hline $\mathrm{ARa}$ & 2528 & 28 & 288 & 2 & 6 & 6 & 0 & 9 & 9 & 3 \\
\hline $\mathrm{ASa}$ & 2100 & 35 & 315 & 1 & 6 & 6 & 0 & 7 & 7 & 0 \\
\hline ATa & 2790 & 36 & 100 & 1 & 10 & 10 & 0 & 9 & 9 & 0 \\
\hline AUa & 2773 & 33 & 88 & 3 & 10 & 10 & 10 & 10 & 10 & 10 \\
\hline $\mathrm{AVa}$ & 2538 & 0 & 212 & 1 & 10 & 10 & 0 & 10 & 10 & 0 \\
\hline AWa & 2700 & 19 & 333 & 3 & 9 & 9 & 9 & 11 & 11 & 11 \\
\hline $\mathrm{AXa}$ & 2810 & 23 & 135 & 1 & 10 & 10 & 2 & 10 & 9 & 4 \\
\hline AYa & 2687 & 9 & 328 & 2 & 9 & 9 & 2 & 10 & 10 & 2 \\
\hline $\mathrm{AZa}$ & 2876 & 7 & 61 & 1 & 10 & 10 & 0 & 10 & 10 & 0 \\
\hline BAa & 2697 & 27 & 111 & 1 & 10 & 10 & 0 & 10 & 10 & 0 \\
\hline $\mathrm{BBa}$ & 2763 & 14 & 103 & 1 & 10 & 10 & 0 & 9 & 9 & 0 \\
\hline $\mathrm{BCa}$ & 2783 & 41 & 357 & 2 & 8 & 8 & 8 & 10 & 10 & 10 \\
\hline $\mathrm{BDa}$ & 2705 & 27 & 247 & 2 & 10 & 10 & 4 & 8 & 8 & 2 \\
\hline $\mathrm{BEa}$ & 2710 & 29 & 167 & 1 & 9 & 9 & 0 & 9 & 9 & 0 \\
\hline $\mathrm{BFa}$ & 2645 & 5 & 31 & 1 & 10 & 10 & 0 & 10 & 10 & 0 \\
\hline $\mathrm{BGa}$ & 2715 & 43 & 246 & 1 & 10 & 10 & 6 & 10 & 10 & 4 \\
\hline ВHa & 2693 & 6 & 243 & 3 & 10 & 10 & 6 & 10 & 10 & 6 \\
\hline BIa & 2362 & 24 & 192 & 1 & 4 & 4 & 0 & 3 & 3 & 0 \\
\hline $\mathrm{BJa}$ & 2997 & 36 & 90 & 2 & 10 & 10 & 10 & 10 & 10 & 7 \\
\hline $\mathrm{BKa}$ & 2691 & 31 & 355 & 2 & 9 & 9 & 9 & 10 & 10 & 4 \\
\hline BLa & 2875 & 19 & 35 & 3 & 10 & 10 & 10 & 9 & 9 & 9 \\
\hline $\mathrm{BMa}$ & 2715 & 44 & 314 & 4 & 10 & 8 & 8 & 9 & 8 & $7^{*}$ \\
\hline Total & & & & & 343 & 319 & 178 & 348 & 325 & 167 \\
\hline
\end{tabular}

5 detected RD, respectively MD. In some cases, small-scale variability can be much higher with a standard deviation of more than 20 days, as shown in Fig. 6 for all footprints. This demonstrates the importance of understanding the limitation of single point measurements for the evaluation of grid-based models.
With a linear regression model, no direct relationship with topography (elevation, slope, sine and cosine of the aspect) or ground cover type could be detected for this or for the difference of the standard deviation between the two years. This difference shows no correlation with the standard deviation. The weak relationship with site-specific factors implies, at least for the short period of observation reported here, that 


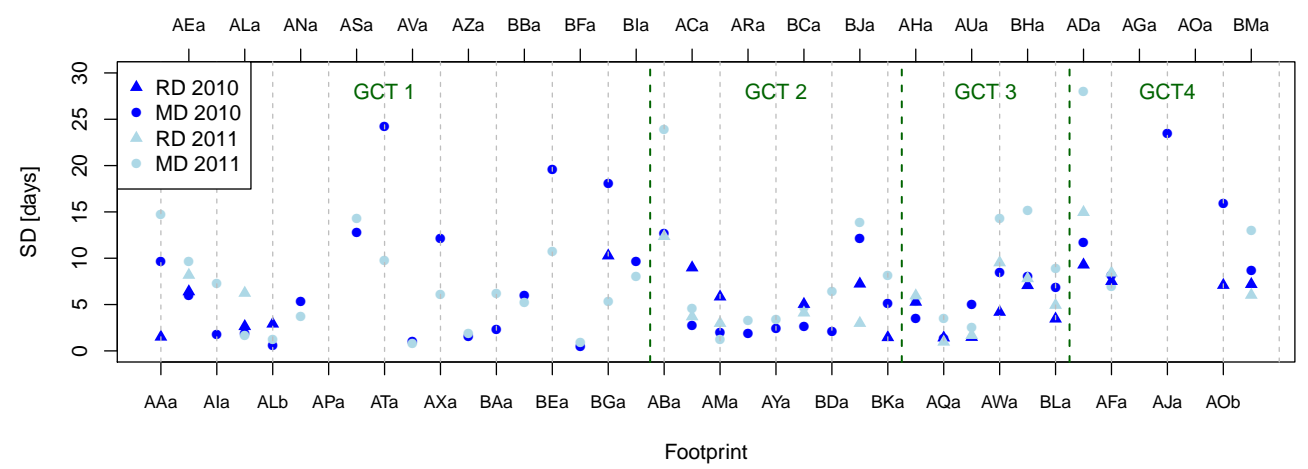

Fig. 6. Standard deviation (SD) for the RD and the MD per footprint for both measuring years. The locations are ordered by their ground cover type (GCT).

meteorological conditions and their influence on processes such as snow drift and deposition exert a dominating control on intra-footprint variability. As a consequence, it is difficult to predict how well one single time series of GST represents $\mathrm{RD}$ and MD for a small area surrounding it or a model grid cell in a validation exercise.

\subsection{Inter-footprint variability}

Mean MD varies from 25 April at ACa to 24 July at AWa in 2010 and from 9 April at ACa to 18 July at BCa in 2011. The mean MD is 15 June in 2010 and 31 May in 2011. RD varies from 23 March at AAa to 11 June at ADa in 2010 and from 22 March at ACa to 5 June at ADa in 2011. The mean RD is 14 May in 2010 and 30 April in 2011. Standard deviations for RD and MD are shown in Fig. 6. RD and MD are shifted towards an earlier date in 2011 with respect to 2010. In 2011, the average RD is 20 days earlier than in 2010 and the MD is on average 12 days earlier than in 2010, taking in account only footprints where $\mathrm{RD}$, respectively $\mathrm{MD}$, were detected for both years. The shift of MD is more pronounced at locations with an early MD, whereas at locations with a late MD, the difference between the two years is much smaller.

For 15 footprints, RD and MD could be detected in both years (Fig. 7). This makes it possible to calculate an average melting period, which lasts from the RD to the MD, for the footprint. At most footprints, GST constantly remains at $0^{\circ} \mathrm{C}$ from $\mathrm{RD}$ to $\mathrm{MD}$, but in few cases GST briefly drops below $0{ }^{\circ} \mathrm{C}$. This can be explained by the reduced insulation of the ground from the atmosphere due to a reduction of snow height and increase in thermal conductivity because of melting. The length change of the melting period is less pronounced with an average melting period for those 15 locations of 37 days in the first year, and 45 days in the second year. No relationship between the melt length and the GCT is visible, even though this has to be interpreted with caution due to the very small sample size.

At the footprint level, the coefficients of determination for the periods 2010 and 2011 are 0.60 and 0.83 between

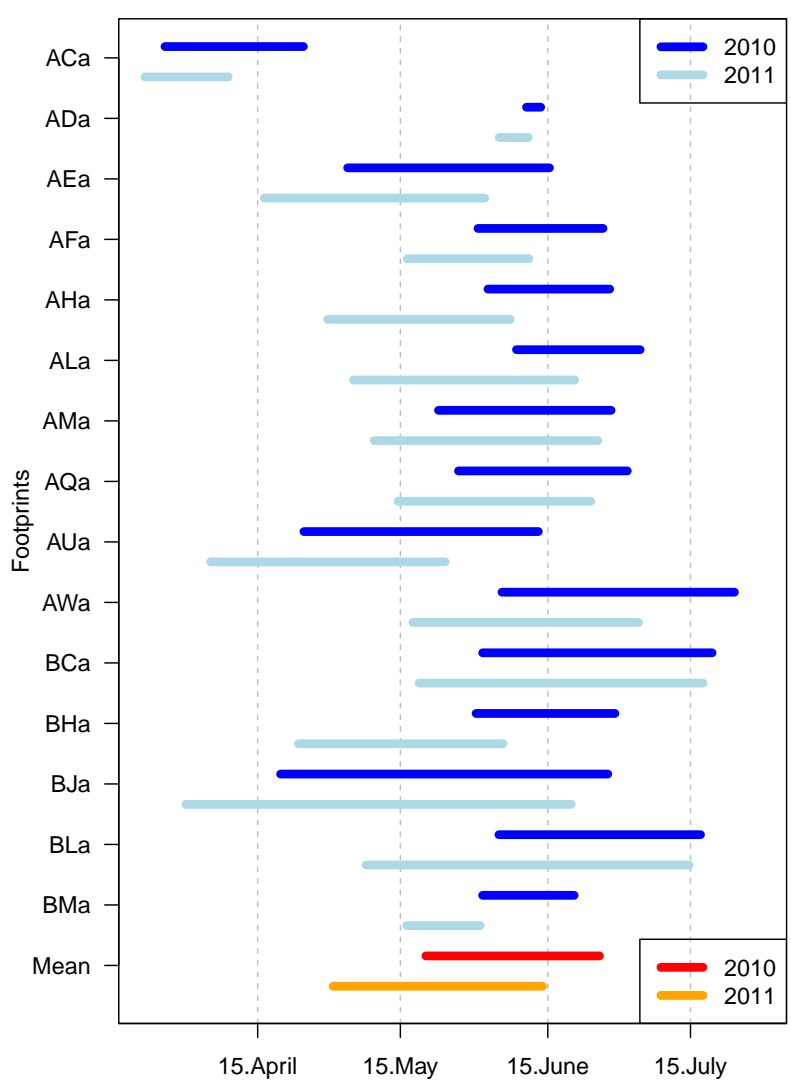

Fig. 7. Melting period defined as the time span between RD and MD for both years of analysis.

MAGST and RD, 0.28 in both years between MAGST and $\mathrm{MD}$, and 0.55 and 0.38 between RD and MD. This suggests that these are useful and complementary metrics for model evaluation.

\subsection{Inter-annual MAGST variations}

The mean intra-footprint standard deviation of MAGST over all footprints is $0.33^{\circ} \mathrm{C}$ in both years. The mean difference of 
intra-footprint standard deviations between 2010 and 2011 is on average $0.1^{\circ} \mathrm{C}$, indicating control of meteorological conditions on this quantity.

At Piz Corvatsch, MAAT during the 2011 analysis period was $0.4^{\circ} \mathrm{C}$ warmer than in 2010 and similar differences were recorded at the nearby stations Samedan and Passo del Bernina. By comparison, MAGST averaged over all footprints increased by $0.17^{\circ} \mathrm{C}$. This is, however, not a uniform response; the mean absolute difference of footprint-level MAGST is $0.27^{\circ} \mathrm{C}$, with 16 cooling and 25 warming footprints.

A comparison of daily mean GST for 2010 and 2011 shows much larger differences during summer than winter (Fig. 8). This can be explained by the effect of a snow cover that provides insulation between the ground and the atmosphere. Both the onset and the melt-out of the snow cover determine whether the seasonal snow cover has a warming or a cooling effect on MAGST (Zhang, 2005). In this study both situations were observed. An absolute quantification is not possible because air temperature has not been measured at any of the snow-covered locations. GST in winter in the second year are slightly warmer than in the first year, even though the snow coverage was thinner in the second winter (Pielmeier, 2011; Stucki, 2010). The difference of MAGST is also strongly influenced by air temperature during the snowfree period. For example, the cold July in 2011 led at all locations to significantly colder GST than in the previous year. Therefore, the average difference of MAGST from the two years is only $0.17^{\circ} \mathrm{C}$.

When looking at inter-annual GST differences and snow cover, a pattern exemplified by the three typical situations in Fig. 8 is visible: at footprints such as AGa or AOa with a low MDr indicative of a thin snow cover, large fluctuations and often slightly warmer temperatures during winter 2011 occurred. For footprints such as ANa or BAa with a high $\mathrm{MDr}$, indicative of an insulating snow cover and a low $\mathrm{RDr}$ indicative of unfrozen ground, GST stayed close to $0^{\circ} \mathrm{C}$ during winter. The earlier MD in 2011, however, caused earlier warming of the ground and a positive difference of GST between the two years in spring. In footprints such as AMa or $\mathrm{AHa}$, with high values of $\mathrm{MDr}$ and $\mathrm{RDr}$ which are indicative of a well-developed snow cover and frozen ground below, a later onset of winter (Stucki, 2010) led to a stronger cooling of the ground and lower GST during winter in the 2010 period. These three classes fit into the classification done by Ishikawa (2003), except that classes 3 and 4 (no shortterm GST fluctuation with gradually increasing or decreasing GST during winter time) are taken as one in this study. The strongly differing reactions of MAGST to the meteorological differences between 2010 and 2011 (some showing warming and some showing cooling), underscores the differences in transient response of frozen ground and permafrost conditions to be expected from climate change, even if the longer-term averaging will likely have a smoothing effect.
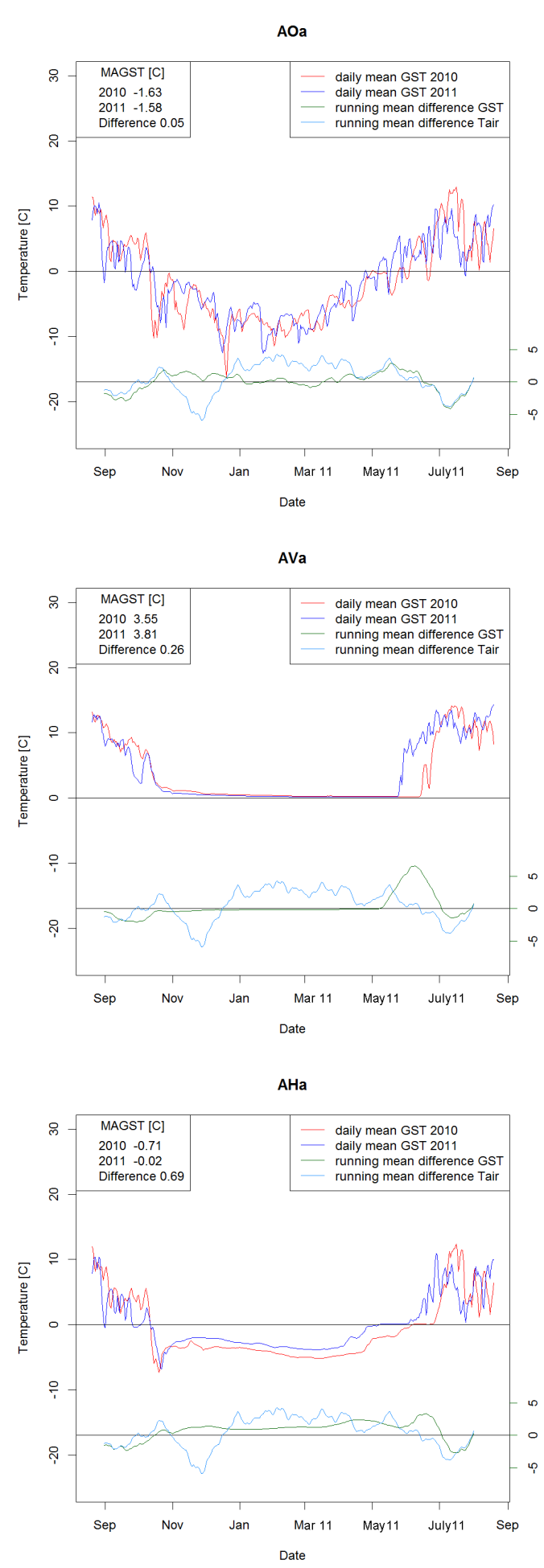

Fig. 8. Differences in the daily GST for footprints with no insulating snow cover (AOa), an insulating snow cover but no frozen ground (Ava), and an insulating snow cover with frozen ground (AHa). Based on air temperature measurements from Piz Corvatsch, the running mean of the difference between the air temperature of the two years is shown. 


\section{Discussion}

The spatial resolution and replication of GST measurements in this study provides a sound basis for deriving RD, MD, and GST, as well as for investigating their spatio-temporal patterns. As measurements are from two years only, results regarding the inter-annual variability and to a lesser degree all absolute values, must be interpreted with caution since meteorological conditions, and especially snow cover, can vary strongly (cf. Brenning et al., 2005; Etzelmüller et al., 2007; Gruber, 2004; Hipp et al., 2011; Hoelzle et al., 2003; Isaksen et al., 2002). Detection of the onset of a snow cover based on GST is inherently uncertain but also of minor importance for model validation as it is much more homogeneous than MD. As MD coincides with rapidly increasing GST, it is also relatively straightforward to detect. MD was only calculated for locations with a comprehensive snow cover, identified based on a standard deviation based reliability index to avoid imprecision. As no suitable ground truth data for RD and MD exists, no direct validation can be performed. The shown methods are to be interpreted as tools for the repeatable extraction of information that could also be interpreted subjectively. In comparison to other published GST-based snow-detection algorithms (Danby and Hik, 2007; Gadek and Leszkiewicz, 2010; Schmidt et al., 2009; Schneider et al., 2012), the method proposed in this study has been tested in a far wider range of topographic situations. MD could be detected at nearly all locations, whereas RD was only detected at half of the locations. RD (the start of the zero curtain in spring) can be detected precisely based on GST where sufficient freezing occurs below the snowpack. While some uncertainties exist for locations with only slightly negative GST below the snowpack, the threshold of at least - 50 FDDs (used in the reliability index RDr) effectively excludes these locations. The possible field of application for RD is more limited, as it only works for a subset of the places at which a snow cover is present. MD has a high correlation with maximum snow height (Anderton et al., 2004), warranting a comparison of this study with results concerning the SWE from Jost et al. (2007).

The average standard deviation of the intra-footprint variability for the RD and the MD is significant, with a length of around one week and a strong variation between footprints. The standard deviation could not be explained by topography or ground cover type, implying that at each new location, an intra-footprint variability much higher than the average can occur. The inter-footprint variability of RD and MD lies between three and four weeks. Absolute values have seen a strong shift between the two years, making both RD and MD earlier in 2011. The differences in the length of the melting period (MD-RD) between 2010 and 2011 are for nearly all footprints smaller than the absolute shift in days (Fig. 7).

The algorithm testing performed with GST and SWE modelled with GEOtop shows that the algorithm developed to detect the MD works on a wide range of topographic situations.
The increasing number of locations where an insulating snow cover is detected the further in the depth GST is modelled shows the damping effect of the ground surface. For the same reason, the error of the MD based on GST develops towards a later MD with increasing depths.

\section{Conclusions}

Based on GST measurements, it is possible to derive MD for all locations with an insulating snow cover and RD if the ground below the snow cover freezes during parts of the winter. The methods described here have been tested in a wide range of topographic situations and provide reproducible results. Because MAGST, RD and MD are only moderately correlated, they are complimentary measures for model validation.

A large intra-footprint variability was observed for both $\mathrm{RD}$ and $\mathrm{MD}$ at many locations. This underscores the importance of using multiple measurement points to characterise one footprint. If validation of a grid-based model with single point measurements is undertaken, a difference of one to three weeks between RD or MD at the measured point and its immediate surroundings must be considered realistic in environments similar to that investigated here.

While based on the comparison of only two years, interannual variation of the GST-derived products provides interesting insight into the importance of snow cover in moderating ground thermal response to atmospheric forcing. The difference in MD between 2010 and 2011 is stronger for locations with an early MD than those with a late MD. This adds to earlier findings of a non-linear relationship between changing environmental conditions and snow cover (Beniston et al., 2003; Schöner et al., 2009). Furthermore, the response of MAGST to a $0.4{ }^{\circ} \mathrm{C}$ increase of MAAT from one year to the other was diverse and included both warming and cooling.

In view of the anticipated environmental changes in cold regions, a GST-based distributed monitoring can provide a cost-effective method for detecting change and for validating models. Due to the strong variability of GST over short distances, the method of sampling fine-scale variability at the footprint level is important for deriving reliable measurements for interpretation or further aggregation.

\section{Supplementary material related to this article is available online at: http://www.the-cryosphere.net/6/ 1127/2012/tc-6-1127-2012-supplement.zip.}


Acknowledgements. This study was funded through the nanotera.ch project X-Sense, the NCCR-MICS project Permasense and the SNF project CRYOSUB. The authors are grateful for the support given by the Corvatschbahnen and acknowledge the contribution of implementing the iAssist software for work-flow automation in the field by M. Keller, J. Beutel, G. Hungerbühler, O. Knecht and Suhel Sheikh of the ETH computer engineering department. As fieldwork was time consuming it would not have been possible without the support of many friends - thanks a lot!

Edited by: A. Nolin

\section{References}

Anderton, S., White, S., and Alvera, B.: Micro-scale spatial variability and the timing of snow melt runoff in a high mountain catchment, J. Hydrol., 268, 158-176, doi:10.1016/S00221694(02)00179-8, 2002.

Anderton, S. P., White, S. M., and Alvera, B.: Evaluation of spatial variability in snow water equivalent for a high mountain catchment, Hydrol. Process., 18, 435-453, doi:10.1002/hyp.1319, 2004.

Bartelt, P. and Lehning, M.: A physical SNOWPACK model for the Swiss avalanche warning Part I: numerical model, Cold Reg. Sci. Technol., 35, 123-145, doi:10.1016/S0165-232X(02)000745, 2002.

Beniston, M., Keller, F., and Goyette, S.: Snow pack in the Swiss Alps under changing climatic conditions: an empirical approach for climate impacts studies, Theor. Appl. Climatol., 74, 19-31, doi:10.1007/s00704-002-0709-1, 2003.

Best, M. J., Pryor, M., Clark, D. B., Rooney, G. G., Essery, R .L. H., Ménard, C. B., Edwards, J. M., Hendry, M. A., Porson, A., Gedney, N., Mercado, L. M., Sitch, S., Blyth, E., Boucher, O., Cox, P. M., Grimmond, C. S. B., and Harding, R. J.: The Joint UK Land Environment Simulator (JULES), model description Part 1: Energy and water fluxes, Geosci. Model Dev., 4, 677-699, doi:10.5194/gmd-4-677-2011, 2011.

Bitner, D., Carroll, T., Cline, D., and Romanov, P.: An assessment of the differences between three satellite snow cover mapping techniques, Hydrol. Process., 16, 3723-3733, doi:10.1002/hyp.1231, 2002.

Blöschl, G., Gutknecht, D., and Kirnbauer, R.: Distributed snowmelt simulations in an Alpine catchment 2. Parameter study and model predictions, Water Resour. Res., 27, 3181-3188, doi:10.1029/91WR02251, 1991a.

Blöschl, G., Kirnbauer, R., and Gutknecht, D.: Distributed snowmelt simulations in an Alpine catchment 1. Model evaluation on the basis of snow cover patterns, Water Resour. Res., 27, 3171-3179, doi:10.1029/91WR02250, 1991b.

Brenning, A., Gruber, S., and Hoelzle, M.: Sampling and statistical analyses of BTS measurements, Permafrost Periglac., 16, 383393, doi:10.1002/ppp.541, 2005.

Brown, R. D.: Northern Hemisphere snow cover variability and change, 1915-97, J. Climate, 13, 2339-2355, doi:10.1175/15200442(2000)013<2339:NHSCVA>2.0.CO;2, 2000.

Dall'Amico, M., Endrizzi, S., Gruber, S., and Rigon, R.: A robust and energy-conserving model of freezing variably-saturated soil, The Cryosphere, 5, 469-484, doi:10.5194/tc-5-469-2011, 2011.
Danby, R. K. and Hik, D. S.: Responses of white spruce (Picea glauca) to experimental warming at a subarctic alpine treeline, Glob. Change Biol., 13, 437-451, doi:10.1111/j.13652486.2006.01302.x, 2007.

Dyer, J. L. and Mote, T. L.: Spatial variability and trends in observed snow depth over North America, Geophys. Res. Lett., 33, doi:10.1029/2006GL027258, 2006.

Endrizzi, S. and Marsh, P.: Observations and modeling of turbulent fluxes during melt at the shrub-tundra transition zone 1: point scale variations, Hydrol. Res., 41, 471-490, 2010.

Essery, R. and Clark, D. B.: Developments in the MOSES 2 landsurface model for PILPS 2e, Global Planet. Change, 38, 161164, doi:10.1016/S0921-8181(03)00026-2, 2003.

Etzelmüller, B., Farbrot, H., Guðmundsson, Á., Humlum, O., Tveito, O. E., and Björnsson, H.: The regional distribution of mountain permafrost in Iceland, Permafrost Periglac., 18, 185199, doi:10.1002/ppp.583, 2007.

Foster, J. L., Hall, D. K., Eylander, J. B., Riggs, G. A., Nghiem, S. V., Tedesco, M., Kim, E., Montesano, P. M., Kelly, R. E. J., Casey, K. A., and Choudhury, B.: A blended global snow product using visible, passive microwave and scatterometer satellite data, Int. J. Remote Sens., 32, 1371-1395, doi:10.1080/01431160903548013, 2011.

Gadek, B. and Leszkiewicz, J.: Influence of snow cover on ground surface temperature in the zone of sporadic permafrost, Tatra Mountains, Poland and Slovakia, Cold Reg. Sci. Technol., 60, 205-211, 2010.

Goodrich, L. E.: The influence of snow cover on the ground thermal regime, Can. Geotech. J., 19, 421-432, 1982.

Groot Zwaaftink, C. D., Löwe, H., Mott, R., Bavay, M., and Lehning, M.: Drifting snow sublimation: A high-resolution 3-D model with temperature and moisture feedbacks, J. Geophys. Res., 116, D16107, doi:10.1029/2011JD015754, 2011.

Gruber, S.: Permafrost thaw and destabilization of Alpine rock walls in the hot summer of 2003, Geophys. Res. Lett., 31, L13504, doi:10.1029/2004GL020051, 2004.

Grünewald, T., Schirmer, M., Mott, R., and Lehning, M.: Spatial and temporal variability of snow depth and ablation rates in a small mountain catchment, The Cryosphere, 4, 215-225, doi:10.5194/tc-4-215-2010, 2010.

Gubler, S., Fiddes, J., Keller, M., and Gruber, S.: Scaledependent measurement and analysis of ground surface temperature variability in alpine terrain, The Cryosphere, 5, 431-443, doi:10.5194/tc-5-431-2011, 2011.

Gutzler, D. S. and Rosen, R. D.: Interannual variability of wintertime snow cover across the Northern Hemisphere, J. Climate, 5, 1441-1447, doi:10.1175/15200442(1992)005<1441:IVOWSC>2.0.CO;2, 1992.

Hipp, T., Etzelmüller, B., Farbrot, H., and Schuler, T. V.: Modelling the temperature evolution of permafrost and seasonal frost in southern Norway during the 20th and 21st century, The Cryosphere Discuss., 5, 811-854, doi:10.5194/tcd-5-811-2011, 2011.

Hoelzle, M., Wegmann, M., and Krummenacher, B.: Miniature temperature dataloggers for mapping and monitoring of permafrost in high mountain areas: first experience from the Swiss Alps, Permafrost Periglac., 10, 113-124, doi:10.1002/(SICI)10991530(199904/06)10:2<113::AID-PPP317>3.0.CO;2-A, 1999. 
Hoelzle, M., Haeberli, W., and Stocker-Mittaz, C.: Miniature ground temperature data logger measurements 2000-2002 in the Murtèl-Corvatsch area, Eastern Swiss Alps, in: Proceedings of the Eighth International Conference on Permafrost, 419-424, 2003.

Isaksen, K., Hauck, C., Gudevang, E., Ødegård, R. S., and Sollid, J. L.: Mountain permafrost distribution in Dovrefjell and Jotunheimen, southern Norway, based on BTS and DC resistivity tomography data, Norsk Geogr. Tidsskrift, 56, 122-136, doi:10.1080/002919502760056459, 2002.

Ishikawa, M.: Thermal regimes at the snow-ground interface and their implications for permafrost investigation, Geomorphology, 52, 105-120, doi:10.1016/S0169-555X(02)00251-9, 2003.

Iverson, R. M., Reid, M. E., and LaHusen, R. G.: Debris-flow mobilization from landslides, Annu. Rev. Earth Pl. Sc., 25, 85-138, doi:10.1146/annurev.earth.25.1.85, 1997.

Jost, G., Weiler, M., Gluns, D. R., and Alila, Y.: The influence of forest and topography on snow accumulation and melt at the watershed-scale, J. Hydrol., 347, 101-115, doi:10.1016/j.jhydrol.2007.09.006, 2007.

Keller, M., Hungerbühler, G., Knecht, O., Skeikh, S., Beutel, J., Gubler, S., Fiddes, J., and Gruber, S.: iAssist: Rapid Deployment and Maintenance of Tiny Sensing Systems, 2010.

Lampkin, D. J. and Yool, S. R.: Monitoring mountain snowpack evolution using near-surface optical and thermal properties, Hydrol. Process., 18, 3527-3542, doi:10.1002/hyp.5797, 2004.

Lehning, M., Bartelt, P., Brown, B., Russi, T., Stöckli, U., and Zimmerli, M.: Snowpack model calculations for avalanche warning based upon a new network of weather and snow stations, Cold Reg. Sci. Technol., 30, 145-157, doi:10.1016/S0165232X(99)00022-1, 1999.

Lehning, M., Bartelt, P., Brown, B., and Fierz, C.: A physical SNOWPACK model for the Swiss avalanche warning Part III: meteorological forcing, thin layer formation and evaluation, Cold Reg. Sci. Technol., 35, 169-184, doi:10.1016/S0165232X(02)00072-1, 2002a.

Lehning, M., Bartelt, P., Brown, B., Fierz, C., and Satyawali, P.: A physical SNOWPACK model for the Swiss avalanche warning Part II. Snow microstructure, Cold Reg. Sci. Technol., 35, 147167, doi:10.1016/S0165-232X(02)00073-3, 2002b.

Li, H.-Y. and Wang, J.: Simulation of snow distribution and melt under cloudy conditions in an Alpine watershed, Hydrol. Earth Syst. Sci., 15, 2195-2203, doi:10.5194/hess-15-21952011, 2011.

López-Moreno, J. I., Fassnacht, S. R., Beguería, S., and Latron, J. B. P.: Variability of snow depth at the plot scale: implications for mean depth estimation and sampling strategies, The Cryosphere, 5, 617-629, doi:10.5194/tc-5-617-2011, 2011.

Luce, C. H., Tarboton, D. G., and Cooley, K. R.: The influence of the spatial distribution of snow on basin-averaged snowmelt, Hydrolog. Process., 12, 1671-1683, 1998.

Luetschg, M. and Haeberli, W.: Permafrost evolution in the Swiss Alps in a changing climate and the role of the snow cover, Norsk Geogr. Tidsskrift, 59, 78-83, doi:10.1080/00291950510020583, 2005.

Lundquist, J. D. and Lott, F.: Using inexpensive temperature sensors to monitor the duration and heterogeneity of snow-covered areas, Water Resour. Res., 44, W00D16, doi:10.1029/2008WR007035, 2008 .
Marsh, C. B., Pomeroy, J. W., and Spiteri, R. J.: Implications of mountain shading on calculating energy for snowmelt using unstructured triangular meshes, Hydrol. Process., 26, 1767-1778, doi:10.1002/hyp.9329, 2012.

Outcalt, S. I., Nelson, F. E., and Hinkel, K. M.: The zerocurtain effect: Heat and mass transfer across an isothermal region in freezing soil, Water Resour. Res., 26, 1509, doi:10.1029/WR026i007p01509, 1990.

Parajka, J. and Blöschl, G.: The value of MODIS snow cover data in validating and calibrating conceptual hydrologic models, J. Hydrol., 358, 240-258, doi:10.1016/j.jhydrol.2008.06.006, 2008.

Pielmeier, C.: Wetter, Schneedecke und Lawinengefahr Hydrologisches Jahr 2010/11, WSL-Insitut für Schnee- und Lawinenforschung SLF, 2011.

Pomeroy, J. W., Marsh, P., and Gray, D. M.: Application of a distributed blowing snow model to the Arctic, Hydrol. Process., 11, 1451-1464, doi:10.1002/(SICI)10991085(199709)11:11<1451::AID-HYP449>3.0.CO;2-Q, 1997.

Rutter, N., Essery, R., Pomeroy, J., Altimir, N., Andreadis, K., Baker, I., Barr, A., Bartlett, P., Boone, A., Deng, H., Douville, H., et al.: Evaluation of forest snow processes models (SnowMIP2), J. Geophys. Res., 114, D06111, doi:10.1029/2008JD011063, 2009.

Scherrer, S. C.: Swiss Alpine snow pack variability: major patterns and links to local climate and large-scale flow, Clim. Res., 32, 187-199, 2006.

Schmid, M.-O.: Variability of ground surface temperatures and related processes in high Alpine regions, MSc., Universty of Zurich, 2011.

Schmidt, S., Weber, B., and Winiger, M.: Analyses of seasonal snow disappearance in an alpine valley from micro- to mesoscale (Loetschental, Switzerland), Hydrol. Process., 23, 10411051, doi:10.1002/hyp.7205, 2009.

Schneider, S., Hoelzle, M., and Hauck, C.: Influence of surface and subsurface heterogeneity on observed borehole temperatures at a mountain permafrost site in the Upper Engadine, Swiss Alps, The Cryosphere, 6, 517-531, doi:10.5194/tc-6-517-2012, 2012.

Schöner, W., Auer, I., and Böhm, R.: Long term trend of snow depth at Sonnblick (Austrian Alps) and its relation to climate change, Hydrol. Process., 23, 1052-1063, doi:10.1002/hyp.7209, 2009.

Stucki, T.: Wetter, Schneedecke und Lawinengefahr, Hydrologisches Jahr 2009/10, WSL-Insitut für Schnee- und Lawinenforschung SLF, 2010.

Taras, B., Sturm, M., and Liston, G. E.: Snow-Ground Interface Temperatures in the Kuparuk River Basin, Arctic Alaska: Measurements and Model, J. Hydrometeorol., 3, 377-394, doi:10.1175/1525-7541(2002)003<0377:SGITIT>2.0.CO;2, 2002.

Techel, F. and Pielmeier, C.: Point observations of liquid water content in wet snow - investigating methodical, spatial and temporal aspects, The Cryosphere, 5, 405-418, doi:10.5194/tc-5-4052011, 2011.

Tribbeck, M. J., Gurney, R. J., Morris, E. M., and Pearson, D. W. C.: A new Snow-SVAT to simulate the accumulation and ablation of seasonal snow cover beneath a forest canopy, J. Glaciol., 50, 171-182, doi:10.3189/172756504781830187, 2004.

Tyler, S. W., Burak, S. A., McNamara, J. P., Lamontagne, A., Selker, J. S., and Dozier, J.: Spatially distributed temperatures at the base of two mountain snowpacks measured with fiber-optic sensors, 
J. Glaciol., 54, 673-679, doi:10.3189/002214308786570827, 2008.

Viviroli, D. and Weingartner, R.: The hydrological significance of mountains: from regional to global scale, Hydrol. Earth Syst. Sci., 8, 1017-1030, doi:10.5194/hess-8-1017-2004, 2004.

Westermann, S., Boike, J., Langer, M., Schuler, T. V., and Etzelmüller, B.: Modeling the impact of wintertime rain events on the thermal regime of permafrost, The Cryosphere, 5, 945-959, doi:10.5194/tc-5-945-2011, 2011.
Williams, M. W., Erickson, T. A., and Petrzelka, J. L.: Visualizing meltwater flow through snow at the centimetre-to-metre scale using a snow guillotine, Hydrol. Process., 24, 2098-2110, doi:10.1002/hyp.7630, 2010.

Wirz, V., Schirmer, M., Gruber, S., and Lehning, M.: Spatiotemporal measurements and analysis of snow depth in a rock face, The Cryosphere, 5, 893-905, doi:10.5194/tc-5-893-2011, 2011.

Zhang, T.: Influence of the seasonal snow cover on the ground thermal regime: An overview, Rev. Geophys., 43, RG4002, doi:10.1029/2004RG000157, 2005. 